Review / Derleme

\title{
Use of three-tier classification system during intrapartum electronic fetal heart rate monitoring
}

\author{
Ali Çetin ${ }^{1}$ \\ Department of Obstetrics and Gynecology, Cumhuriyet University School of Medicine, \\ TR-58140 Sivas
}

\begin{abstract}
Evaluation of the fetal heart rate (FHR) for obtaining essential information is required for fetal risk assessment during labor and birth and it is helpful for the detection of potential harmful effects on fetal systems and for allowing timely and effective interventions to prevent perinatal/neonatal morbidity or mortality. Electronic FHR monitoring (EFM) is the most widely used method of intrapartum surveillance of fetal well-being. The most apparent problem with the use of EFM in maternity wards is the wide variability with which obstetricians interpret and respond to its findings in labor ward settings. There are many FHR patterns that lie between the completely reassuring patterns and those considered ominous. ACOG's Practice Bulletin 116 recommends the use of the three-tier classification system for FHR tracings. Category 1 FHR tracings are considered normal and no specific action is required. Category 2 tracings are considered indeterminate. This category requires evaluation and surveillance and possibly other tests to ensure fetal well-being. Category 3 tracings are considered abnormal and require prompt evaluation.
\end{abstract}

Key words: Electronic fetal monitoring, fetal heart rate, intrapartum

Özet

Doğum eylemi ve doğum sırasında fetal risk durumu hakkında değerli bilgiler elde etmek için fetal kalp hızının (FKH) değerlendirmesi gerekir ve bu değerlendirme fetal sistemler üzerine olası zararlı etkilerin saptanmasına ve perinatal/neotanatal morbidite ve mortalitenin önlenmesi için zamanında ve etkin önlemlerin alınmasında yardımcı olur. Elektronik fetal kalp hızı monitorizasyonu (EFM), intrapartum fetal iyilik halinin

\footnotetext{
${ }^{1}$ Corresponding author:

Dr. Ali Çetin, Kadın Hastalıkları ve Doğum AD, Cumhuriyet Üniversitesi Tıp Fakültesi, TR-58140 Sivas.

Email: dralicetin@gmail.com
} 
izlenmesinde en sık kullanılan yöntemdir. Doğumhanelerde EFM kullanımı ile ilişkili en belirgin sorun, doğum hekimlerinin doğumhane koşullarında EFM bulgularını değerlendirmesinin ve bunlara karşı yaptıkları girişimlerin çok farklı olabilmesidir. Çok sayıda FKH paterni tamamen sağlıklı olanlarla tehlikeli olanların arasında bulunur. ACOG Pratik Bülteni $116 \mathrm{FKH}$ traseleri için üç aşamalı sınıflama sistemini önermektedir. Kategori $1 \mathrm{FKH}$ traseleri normal kabul edilir ve özellikli bir önlem gerekmez. Kategori 2 traseleri arada kabul edilir. Bu kategori değerlendirme ve izleme gerektirir ve fetal iyilik halini gösteren diğer testlere intiyaç olabilir. Kategori 3 traseleri anormal kabul edilir ve hemen değerlendirme gerektirir.

Anahtar sözcükler: Elektronik fetal monitorizasyon, fetal kalp hızı, intrapartum

\section{Introduction}

Since electronic fetal monitoring (EFM) was first introduced into clinical practice in the late 1960s, progress and consensus in its status was restricted by a lack of standardization it its definitions and interpretation. In 1995 and 1996, the National Institute of Child Health and Human Development (NICHD) conducted a panel discussion in the EFM with the goal of reaching consensus on a set of standardized, unambiguous definitions for fetal heart rate (FHR) tracings. In 2008, the Eunice Kennedy Shriver NICHD, American College of Obstetricians and Gynecologists, and the Society for Maternal-Fetal Medicine conducted a second meeting to review and clarify the 1997 definitions, to propose a standard classification system for FHR tracings, to introduce, in consensus form, key concepts of intrapartum FHR interpretation, and to make recommendations for future research [1]. The most important addition of that consensus is the use of 3 categories for classifying FHR patterns. As the evidence behind the usage of such categories has yet to be shown, these categories do provide care providers with a simple language of communication. Thus, the 2008 NICHD workshop document provides standard descriptive vocabulary and classification criteria for all providers to work with [2]. Refinements of the definitions, classifications, and interpretations of fetal heart rate (FHR) monitoring methods were issued in a new guideline released by The American College of Obstetricians and Gynecologists (ACOG) [3]. The objective of that guideline is to reduce the inconsistent use of common terminology and the wide variability that sometimes occurs in FHR interpretations. ACOG's Practice Bulletin 116 supports the recommendations of the 2008 NICHD workshop on EFM.

The goal of FHR monitoring is to follow up the status of the fetus during labor and intervene when it is required. Two FHR findings reliably predict the absence of acidemia: (1) the presence of FHR accelerations, either spontaneous or stimulated, or (2) moderate FHR variability. It must be emphasized, however, that although either fetal accelerations or moderate FHR variability reliably predict the absence of acidemia, the absence of accelerations, the presence of minimal variability, or the presence of absent variability does not reliably predict the presence of fetal hypoxemia or metabolic 
acidemia. The significance of marked variability (formerly described as saltatory) remains unclear [4].

\section{Three-tier system for classifying fetal heart rate tracings}

Over the years, objective fetal interpretation of FHR has been subject to much debate. Numerous studies have documented the poor inter- and intra- observer reliability for the interpretation of FHR tracings. [2,5]. One notable update in the ACOG's Practice Bulletin 116 is the three-tier classification system for FHR tracings. Category I FHR tracings are reassuring and fetal acidosis at the time of observation can be excluded, and no specific action is required. Category II FHR tracings are considered "indeterminate" and comprise the majority of FHR tracings [R6].

Category II tracings require further evaluation and monitoring, as they are not predictive of fetal acidosis, but there is not enough data to include them in either Category I or III. Category II FHR tracings include indeterminate FHR tracings, such as bradycardia or tachycardia, with minimal variability. Other aspects of indeterminate tracings include minimal baseline variability with marked or no recurrent decelerations; no accelerations after fetal stimulation; periodic or episodic decelerations with recurrent variable decelerations and minimal or moderate baseline variability; prolonged decelerations, recurrent late decelerations with moderate baseline variability; or variable decelerations with other characteristics, such as a slow return to baseline, and "overshoots" or "shoulders." These findings are common during labor and require the obstetrician to be ever vigilant in monitoring labor progress and the fetal response to uterine activity $[3,6$, 7].

Category III tracings are abnormal and predictive of fetal acidosis when observed. Prompt evaluation is warranted and in utero resuscitative efforts should be considered, including maternal oxygen administration, changing the maternal position, discontinuation of labor stimulation, and addressing maternal hypotension $[3,6]$.

Table 1. Three-tier system for classifying fetal heart rate tracings.

\begin{tabular}{|l|l|l|}
\hline Category & Description & Interpretation \\
\hline Category & $\begin{array}{l}\text { Normal tracings, which are strongly predictive of normal fetal acid- } \\
\text { base status at the time of observation and can be followed in a } \\
\text { routine manner without any specific action required, include all of } \\
\text { the following: } \\
\text { Baseline rate: } 110-160 \text { beats/min } \\
\text { Moderate variability } \\
\text { Absence of any late or variable decelerations } \\
\\
\begin{array}{ll}\text { Early decelerations may or may not be present } \\
\text { Accelerations may or may not be present }\end{array}\end{array}$ & \\
\hline II & $\begin{array}{l}\text { Indeterminate tracings, although not predictive of abnormal fetal } \\
\text { acid-base status, cannot be classified as Category I or III and thus } \\
\text { require evaluation and continued surveillance and reevaluation. } \\
\text { These tracings are not infrequently encountered in clinical care, and } \\
\text { include any of the following: } \\
\text { Baseline rate } \\
\text { Tachycardia }\end{array}$ & \\
\hline
\end{tabular}




\begin{tabular}{|c|c|c|}
\hline & $\begin{array}{l}\text { Bradycardia not accompanied by absent baseline variability } \\
\text { Baseline FHR variability } \\
\text { Minimal baseline variability } \\
\text { Absent baseline variability not accompanied by recurrent } \\
\text { decelerations } \\
\text { Marked baseline variability } \\
\text { Absence of induced accelerations after fetal stimulation (eg, scalp } \\
\text { stimulation, vibroacoustic stimulation, direct fetal scalp sampling, } \\
\text { transabdominal halogen light) } \\
\text { Periodic or episodic decelerations } \\
\text { Recurrent variable decelerations accompanied by minimal or } \\
\text { moderate baseline variability } \\
\text { Prolonged deceleration } \geq 2 \text { min but }<10 \text { min } \\
\text { Recurrent late decelerations with moderate baseline variability } \\
\text { Variable decelerations with other characteristics, such as slow } \\
\text { return to baseline, "overshoots," or "shoulders" }\end{array}$ & \\
\hline $\begin{array}{l}\text { Category } \\
\text { III }\end{array}$ & $\begin{array}{l}\text { Abnormal tracings, which are predictive of abnormal fetal acid-base } \\
\text { status at the time of observation, require prompt evaluation and } \\
\text { initiation of expeditious attempts to resolve the abnormal FHR } \\
\text { pattern, such as provision of maternal oxygen, change in maternal } \\
\text { position, discontinuation of labor stimulation, treatment of } \\
\text { maternal hypotension, or additional efforts. These tracings include } \\
\text { either: } \\
\text { Absent baseline FHR variability along with any of the following: } \\
\text { Recurrent late decelerations } \\
\text { Recurrent variable decelerations } \\
\text { Bradycardia } \\
\text { Sinusoidal pattern }\end{array}$ & Abnormal \\
\hline
\end{tabular}

\section{Clinical Recommendations $[3,8]$}

Specific clinical recommendations and conclusions in the revised ACOG guidelines that are based on good and consistent scientific evidence (level A) include the following:

- Category I FHR tracings may be managed in a routine manner because they are not associated with fetal acidemia.

- A Category III FHR tracing is abnormal and conveys an increased risk of fetal acidemia at the time of observation.

- Amnioinfusion has been shown to decrease the recurrence of variable decelerations as well as the rate of cesarean delivery for abnormal FHR patterns.

- The false-positive rate of EFM for predicting cerebral palsy exceeds $99 \%$.

- The use of EFM is linked to higher rates of both vacuum and forceps operative vaginal delivery, as well as of cesarean delivery for abnormal FHR patterns and/or acidosis.

- Recurrent variable decelerations on the FHR tracing should lead to consideration of amnioinfusion to relieve umbilical cord compression.

- For assessing fetal status, pulse oximetry has not been shown to be clinically useful. 
Specific clinical recommendations and conclusions in the revised ACOG guidelines that are based on inconsistent scientific evidence (level B) include the following:

- Intravenous fluid bolus, lateral positioning and oxygen administration, when used together, may improve fetal oxygenation during labor.

- Regardless of whether labor is spontaneous or stimulated, tachysystole accompanied by Category II or Category III FHR tracing requires evaluation and initiation of appropriate treatment.

- Category II tracings require evaluation, continued surveillance, initiation of appropriate corrective measures when indicated, and reevaluation. The presence of FHR accelerations (whether spontaneous or elicited) or moderate FHR variability or both are highly predictive of normal fetal acid-base status and, thus, may help guide clinical management.

- Interpretation of FHR tracing is subject to high interobserver and intraobserver variability.

- Reinterpretation of the FHR tracing may not be reliable, especially once the neonatal outcome is known.

- Use of EFM is not associated with a lower incidence of cerebral palsy.

Specific clinical recommendations based on expert opinion (level C) include the following:

- A 3-tiered system is recommended to categorize FHR patterns.

- The optimal time frame to affect delivery in the setting of a Category III FHR tracing has not been established.

- During labor, women with high-risk conditions should undergo continuous FHR monitoring.

When EFM is used during labor, the nurses or physicians should review it frequently, according to the authors of the the guidelines, in a patient without complications, the FHR tracing should be reviewed approximately every 30 minutes in the first stage of labor and every 15 minutes during the second stage; and the corresponding frequency for the patients with high-risk pregnancies (e.g., fetal growth restriction, preeclampsia) is approximately every 15 minutes in the first stage of labor and every 5 minutes during the second stage $[3,8]$.

In summary, use of three-tier classification system during intrapartum EFM with recommended standards can be helpful for obstetricians and midwives to determine the management of labor although this system has limitations because Category II tracings are "everything else," including patterns that are "indeterminate" and inconsistently associated with fetal acidemia. 


\section{References}

1. Hankins GD, Miller DA. A Review of the 2008 NICHD Research Planning Workshop: Recommendations for Fetal Heart Rate Terminology and Interpretation. Clin Obstet Gynecol. 2011 Mar;54(1):3-7.

2. Pettker $\mathrm{CM}$. Standardization of intrapartum management and impact on adverse outcomes. Clin Obstet Gynecol. 2011 Mar;54(1):8-15.

3. American College of Obstetricians and Gynecologists. Practice bulletin no. 116: Management of intrapartum fetal heart rate tracings. Obstet Gynecol. 2010 Nov;116(5):1232-40.

4. Robinson B, Nelson L. A Review of the Proceedings from the 2008 NICHD Workshop on Standardized Nomenclature for Cardiotocography: Update on Definitions, Interpretative Systems With Management Strategies, and Research Priorities in Relation to Intrapartum Electronic Fetal Monitoring. Rev Obstet Gynecol. 2008 Fall;1(4):186-92.

5. Graham EM, Petersen SM, Christo DK, Fox HE. Intrapartum electronic fetal heart rate monitoring and the prevention of perinatal brain injury. Obstet Gynecol. 2006 Sep;108(3 Pt 1):656-66.

6. Farley D, Dudley DJ. Fetal assessment during pregnancy. Pediatr Clin North Am. 2009 Jun;56(3):489-504.

7. Macones GA, Hankins GD, Spong CY, Hauth J, Moore T. The 2008 National Institute of Child Health and Human Development workshop report on electronic fetal monitoring: update on definitions, interpretation, and research guidelines. Obstet Gynecol. 2008 Sep;112(3):661-6.

8. American College of Obstetricians and Gynecologists. ACOG Practice Bulletin No. 106: Intrapartum fetal heart rate monitoring: nomenclature, interpretation, and general management principles. Obstet Gynecol. 2009 Jul;114(1):192-202. 